\title{
MODEL DAN PEMANFAATAN PENELITIAN ETNOGRAFI DALAM DUNIA PENDIDIKAN
}

\author{
Reksiana \\ Institut Ilmu Al-Quran (IIQ) Jakarta \\ Email: reksiana@iiq.ac.id
}

\begin{abstract}
This study discusses about the ethonographic approach in educational research. Ethnographic research, at first, was widely used in anthropological research, and developed in various fields of science such as medicine, health, psychology, and education and other social sciences. then, it can be concluded that there are four types of ethnographic research analysis in Spredley's model, they are: domain analysis, taxonomic analysis, compound analysis, and model analysis (ethnographic results. The qualitative research stages of the Spradley model consisted of 12 stages starting with determining a reliable or accurate key informant. Next, do an interview. Then, the researcher began asking descriptive questions, with an analysis of the interview. The results of the interview analysis, then the researcher conducted a domain analysis. In the next step, the researcher has determined the focus, and conduct a taxonomic analysis, then the researcher asks contrast questions, which are followed by a comparative analysis. The results of the comparative analysis, then the researcher found cultural themes. And the final step, the researcher wrote an ethnographic research report. And of course all of these stages must be adjusted to the field of education if research is in the field of education.
\end{abstract}

Keyword: Ethnography Research, Ethnography Approach, Etnografi in Education. 


\begin{abstract}
Abstrak
Penelitian etnografi pada mulanya banyak digunakan dalam penelitian antropologi, dan berkembang dalam berbagai bidang ilmu seperti kedokteran, kesehatan, psikologi, dan pendidikan serta ilmu sosial lainnya. Maka, dapat disimpulkan bahwa Empat jenis analisis penelitian etnografi dalam model Spredley yaitu analisis domain, analisis taksonomi, analisis komponensial, dan analisis model (hasil etnografi). Tahapan penelitian kualitatif model Spradley terdiri atas 12 tahapan dimulai dengan menetapkan seorang informan kunci (key informant) yang handal atau akurat. Selanjutnya, melakukan wawancara. Kemudian, peneliti memulai mengajukan pertanyaan deskriptif, dengan analisis terhadap wawancara. Hasil dari analisis wawancara, selanjutnya peneliti melakukan analisis domain. Pada langkah berikutnya, peneliti sudah menentukan fokus, dan melakukan analisis taksonomi, selanjutnya peneliti mengajukan pertanyaan kontras, yang dilanjutkan dengan analisis komponensial. Hasil dari analisis komponensial, selanjutnya peneliti menemukan tema-tema budaya. Dan di akhir, peneliti menuliskan laporan penelitian etnografi. Dan tentunya semua tahapan ini harus disesuaikan oleh peneliti jika meneliti dalam bidang pendidikan.
\end{abstract}

Kata Kunci: Penelitian Etnografi, Pendekatan Etnografi, Penelitian Etnografi dalam Pendidikan 


\section{Pendahuluan}

Dalam dunia akademis, sejatinya penentuan pendekatan penelitian oleh peneliti bukan tanpa dasar, pendekatan penelitian mencakup kepakaran, berbagai asumsi dan tindakan dapat digunakan oleh peneliti ketika bergerak dari paradigma dalam memperoleh dan mengumpulkan data empiris di lapangan.

Dengan demikian, suatu keniscayaan seorang penliti harus dapat menentukan pendekatan penelitian tersebut, dan harus disesuaikan dengan setting penelitian dengan memunculkan pertanyaan penelitian. Di dalam sebuat penelitian tentunya ada banyak jenis pendekatan, dan salah satunya yaitu pendekatan penelitian etnografi, di mana dalam beberapa waktu ini jenis pendekatan ini telah banyak dipilih oleh para peneliti (Windiani, Nuru, 2016: 87-92)

Menurut Windiani dan Farida Nurul, adanya kecenderungan para peneliti memilih menggunakan pendekatan etnografi, karena pendekatan ini lebih dapat dipahami dengan mudah. Bahkan, menurut keduanya, peneliti dapat membayangkan dengan sangat mudah hanya dapat melukiskan suatu kelompok etnik. Namun pada realitas yang sebenarnya di lapangan, hal ini tidaklah semudah yang demikian, karena etnografi juga mempunyai kaidahnya yang harus diikuti, mempunyai beberapa tataran akademik yang harus dipilih, dan pada gilirannya dapat menggunakan dalam penelitian dengan penuh bertanggung jawab (Sukadari, Suyata, dan Kuntoro, 2015: 58-68).

Etnografi merupakan pekerjaan mendeskripsikan suatu kebudayaan. Tujuan utamanya adalah untuk memahami suatu pandangan hidup dari sudut pandang penduduk asli. Selain itu, inti etnografi yatu upaya untuk memperhatikan makna-makna tindakan dari kejadian yang menimpa orang yang ingin kita pahami. Lebih lanjut, untuk memahami dan mendeskripsikan budaya dari perspektif ini, seorang peneliti harus memikirkan peristiwa-peristiwa atau fenomena-fenomena dengan cara berpikirnya. Seorang peneliti etnografi harus menerangkan perilaku manusia dengan menguraikan apa yang ia ketahui, yang membuat dirinya mampu berperilaku sesuai dengan perilaku umum dari masyarakat yang diteliti (Naidoo, 2012).

Etnografi berkembang sebagai alat ilmu sosial, dan melibatkan ilmu sosial pengamat, yang diamati, laporan penelitian sebagai teks, dan fenomena yang menjadi yang dijadikan objek dan kemudian disajikan dengan bentuk narasi atau teks. Ilmu-ilmu sosial diharapkan menjadi semacam itu kredibilitas ilmu fisika, dan pendekatan awal seperti ilmu fisika di dalamnya. Diasumsikan bahwa peneliti memiliki hak untuk mempelajari fenomena apapun asalkan mengarah ke pengetahuan baru, dan satu-satunya sudut pandang adalah dari peneliti. Ada kecenderungan untuk mengabaikan subjek atau bersikap kritis terhadap klaim mereka, mereka dipandang sebagai peserta pasif dalam penelitian, tanpa berdampak pada isi penelitian. Garis di antara peneliti dan penelitian didefinisikan dengan jelas, dan ini juga berlaku untuk teks yang dihasilkan dan penonton yang diproduksi. Hanya peneliti yang memiliki masukan untuk laporan akhir, dan produk ini pada gilirannya, sebagian besar menjadi milik komunitas ilmiah. ${ }^{1}$

Salah satu pendekatan utama dari penelitian kualitatif ialah penelitian Etnografi yang dikenal juga sebagai penelitian budaya antropologi atau kadang disebut dengan Naturalistic Inquiry. Asal disipliner keiluman dari penelitian ini menurut Hemant Lata dan Chiranjit Sarka adalah Antropologi. Dan penelitian 
Etnografi berkaitan dengan penemuan dan deskripsi budaya suatu kelompok atau kelompok individu. Menurut keduanya juga konsep budaya merupakan tema sentral dalam penelitian etnografi (Kruger, 2010: 52-74).

Lebih lanjut, bahwa penelitian etnografi membantu peneliti dalam mencari tantangan yang berhubungan dengan suatu fenomena yang sangat rumit atau kompleks. Seorang peneliti yang hebat dan efektif dibutuhkan saat dia sedang melihat atau mengamati atau berinteraksi dengan populasi sasaran dalam situasi kehidupan nyata mereka. Penelitian etnografi adalah salah satu penelitian kualitatif terpenting di mana peneliti mengamati atau berinteraksi dengan sasaran populasi dan peneliti berperan penting untuk mendapatkan informasi budaya yang bermanfaat, dan itu sebabnya penelitian etnografi dikenal dengan istilah etnografi budaya atau antropologi budaya (Kruger, 2010: 52-74).

Heinz Herman Kruger mengatakan, penelitian etnografi adalah salah satu metode kualitatif yang tertua dari riset sosial. Metode ini sangat tepat untuk meneliti masalah budaya, dan biasanya selalu terpilih sebagai metode penelitian antropologi. Mengenai implementasi penggunaan model dan analisa pada penelitian sosial terklasifikasi dalam beberapa bentuk, diantaranya seperti studi kesejarahan, studi sosiologi, dan antroplogi. Model tersebut menjadi indikator dalam melakukan studi sosial di masyarakat. Hal itu berperan untuk memberikan rancangan instrumen dan target hasil yang hendak dicapai. Posisi studi etnografi termasuk dalam penelitian sosial. Etnografi merupakan cabang antropologi yang digunakan untuk menggambarkan, menjelaskan, dan menganalisis, unsur suatu kebudayaan atau bangsa. Dalam pandangan Koentjaraningrat dinyatakan bahwa isi dari etnografi mengenai suatu deskripsi tentang kebudayaan etnik dari suatu suku bangsa secara holistik (keseluruhan) (Kruger, 2010: 52-74).

Dalam penelitian Eriksson dkk. penelitian etnografi digambarkan sebagai deskripsi tertulis mengenai organisasi sosial, aktivitas sosial, simbol dan sumber meterial, serta karakteristik praktik interpretasi suatu kelompok manusia tertentu. Pada dasarnya perhatian utama penelitian etnografi yaitu tentang tata cara dan kehidupan suatu masyarakat. Selain itu, dalam penelitian Eriksson dkk etnografi tidak hanya mempelajari masyarakat, tetapi juga belajar dari masyarakat. Karena esensi penelitian etnografi tidak hanya mengambil simpulan dari kebudayaan masyarakat saja, tetapi juga mengambil hikmah dan pelajaran sosial dari kebudayaan tersebut. Dan pada saat ini penelitian etnografi sudah banyak mengalami perubahan termasuk yang telah dilakukan oleh Spredley. Etnografi pada saat ini berkembangan tidak hanya pada beberapa lini bidang ilmu seperti, kedokteran, psikologi bahkan termasuk pada dunia pendidikan (Eriksson and Kovalainen, 2010: 63-149).

Penelitian etnografi dalam dunia pendidikan sudah menjadi hal yang tergolong lazim pada saat ini. Hal ini dapat dilihat dalam studi dilakukan oleh Sukadari dkk. Dalam peneltian tersebut, mereka menggunakan desain penelitian etnografi dalam dunia pendidikan. Data dalam penelitian ini berupa gambaran yang mendalam dan akurat atas semua aktivitas subjek berdasarkan perspektif lapangan yang didapatkan oleh peneliti. Sukadari dkk melakukan refleksi dengan informan terhadap sikap, ucapan, dan semua kegiatan yang biasa dilakukan dalam kehidupan sehari-hari sehingga terjadi penafsiran interkoneksi atau intersubjektif. Sehingga didapat kan hasil interpretasi dari pengamatan lapangan yang kemudian direlasikan dengan kerangka teori yang telah dibangun untuk menemukan jawaban dari permasalahan yang dikaji dalam penelitian ini. Dan semua data 
tersebut menggunakan teknik analisis kualitatif etnografi. Penelitian etnografi dipakai oleh Sukadari dkk sebagai cara untuk menyajikan data secara menyeluruh yang berkait dengan tindakan objek yang teliti (Sukadari, Suyata, dan Kuntoro, 2015).

Selanjutnya, secara seksama dapat diketahui perbedaan penelitian tersebut dengan penelitian ini dalam beberapa hal seperti; pertama, aspek metode dan jenis penelitian serta dan sumber data. Kedua, dalam aspek analisis data yang digunakan, bahwa penelitian Sukadari mengambil setting objek penelitian di sekolah, sementara penelitian ini megambil setting penelitian library research (Sukadari, Suyata, dan Kuntoro, 2015).

Penelitian etonografi saat ini dapat dimanfaatkan dalam semua bidang termasuk dalam bidang pendidikan. Sebagai contoh dalam studi yang dilakukan oleh Jean S. Lee yang memberikan jawaban atas kritik etnografi tradisional. Dengan adanya inovasi peneltian etonografi dalam berbagai bidang sosial termasuk dalam bidang pendidikan, etnografi saat ini tidak hanya terfokus pada bidang antropologi, kini berkembang dalam berbagai bidang ilmu seperti kedokteran, kesehatan, psikologi Itu inovatif untuk diterapkan, bahkan dalam bidang ilmu pendidikan (Lee, Nargund-Joshi, dan Dennis, 2011: 42-57).

Selanjutnya, pada artikel kali ini penulis membahas bagaimana mengadaptasi langkah analisis penelitian etnografi ke studi kasus yang dapat memberikan kontribusi pada metodologi pendidikan. Menurut Jean S. Lee bahwa di dalam etnografi dapat berguna untuk mengartikulasikan konseptualisasi implisit dalam studi kasus pada bidang pendidikan, salah satunya dalam pendidikan sains dan selain dari pendidikan matematika. Etnografi dalam bidang pendidikan dapat menyelidiki masalah yang dapat melibatkan pencarian pada data terdekat dalam aspek substantif dari studi kasus itu sendiri. Temuan dari kasus tersebut studi dan hasil dari penyelidikan etonografi dilaporkan bersama dengan saran untuk penelitian di masa depan (Lee, Nargund-Joshi, dan Dennis, 2011: 42-57).

Dengan demikian tentunya menjadi layak untuk membahas dan mengkaji penelelitian etnografi dalam dunia pendidikan, termasuk bagaimana tahapan dan implementasinya dalam bidang tersebut. Tulisan ini diawali dengan latar belakang etnografi, kemudian mendiskusikan dan mengkaji diskursus tentang penggunaan dan pemanfaatn penelitian etnografi dalam bidang pendidikan.

\section{Metodologi Penelitian}

Dalam penelitian ini, metode yang dgunakan ialah metode kepustakaan (library research). Metode studi pustaka atau kepustakaan (library research) dapat diartikan sebagai serangkaian kegiatan yang berkenaan dengan metode pengumpulan data pustaka, membaca dan mencatat serta mengolah bahan penelitian. (Mestika Zed: 2003, p.4-5).

Kemudian dalam penelitian metode kepustakaan terdapat empat aspek atau langkah yang digunakan, dengan ciri utama yang gunakan dalam penelitian kepustakaan yaitu: Pertama, data yang didapatkan oleh penulis berupa hasil-hasil penelitian etnografi dalam bidang pendidikan, buku, jurnal, artikel otoritatif. Kedua, data yang didapatkan oleh peneliti adalah data pustaka yang bersifat "siap pakai" artinya peniliti tidak terjun langsung kelapangan karena peneliti berhadapan langsung dengan sumber data yang ada di perpustakaan. Ketiga, bahwa data pustaka umumnya adalah sumber sekunder, dalam arti bahwa peneliti memperoleh bahan atau data dari tangan kedua dan bukan data orisinil dari data 
pertama di lapangan. Keempat, bahwa kondisi data pustaka tidak dibatasi oleh runga dan waktu. (Mestika Zed: 2003, p.4-5).

Proses selanjutnya, pengumpulan data dalam penelitian ini dilakukan dengan menelaah dan/atau mengekplorasi beberapa jurnal, buku, dan dokumendokumen (baik yang berbentuk cetak maupun elektronik) serta sumber-sumber data dan atau informasi lainnya yang dianggap relevan dengan penelitian atau kajian yang otoritatif. Tahapan selanjutnya yaitu teknik analisis data dengan gambaran sebagai berikut: Penulis membaca dan memahami semua doikumen junral hasil penelitian, buku, artikel dan lain-lain secara utuh. Kemudian, penulis mengidenfikasi, mencatat dan melakukan penyaringan data yang terdapat dalam buku.

Kemudian, penulis melakukan coding, yaitu memilah isi atau bagian-bagian dari buku yang sesuai dan dibutuhkan dalam penelitian ini. Adapun yang tidak sesuai diabaikan. Setelah hal tersebut dilakukan, penulis mengumpulkan dan mendokumentasikan bagian-bagian buku, jurnal, artikel dan lain-lain, yang diperlukan sebagai data penelitian. Penulis melakukan analisis dan interpretasi data yang sesuai dengan rancangan penelitian. Tahap akhir, penulis mengumpulkan hasil analisis data ke dalam sebuah laporan hasil penelitian. Selanjutnya, penulis mendiskusikan laporan hasil penelitian tersebut.

\section{Pembahasan}

\section{Definisi dan Prinsip-prisip dalam Penelitian Etnografi}

Sebelum lebih jauh mendiksusi bagaimana tahapan dalam penelitian etnografi, maka akan dibahas terlebih dahulu defenisi penelitian etnografi. Hal ini dianggap perlu, karena dengan mendiskusikan defenisi tersebut, akan ditemukan pengertian dan makna dari penelitian.

Defenisi etnografi menjadi dasar yang penting untuk memahaminya lebih lanjut lagi. Dalam hal ini, etnografi berasal dari bahasa Yunani, ethnos yang berarti orang dan graphein yang berarti tulisan. Terdapat pengertian lain yang semakna, di mana secara harfiah etnografi diartikan sebagai tulisan atau laporan tentang suatu suku bangsa yang ditulis oleh seorang antropolog atas hasil penelitian lapangan (field work). Secara klasifikasi, etnografi termasuk ke dalam penelitian kualitatif (Kamarusdiana, 2019: 113-28).

Etnografi merupakan suatu metode penelitian ilmu sosial. Penelitian ini sangat percaya pada ketertutupan, pengalaman pribadi,dan partisipasi yang mungkin, tidak hanya pengamatan, oleh para peneliti yang terlatih dalam seni etnografi. Para etnografer ini sering bekerja dalam tim yang multidisipliner. Di mana titik fokus penelitiannya dapat meliputi studi intensif budaya dan bahasa, bidang atau domain tunggal, ataupun gabungan metode historis, observasi, dan wawancara. Pada awalnya etnografi berakar pada bidang antropologi dan sosiologi. Namun para praktisi dewasa ini melaksanakan penelitian etnografi dalam segala bentuk. Ahli etnografi melakukan studi persekolahan, kesehatan masyarakat, perkembangan pedesaan dan perkotaan, konsumen dan barang konsumsi, serta arena ataupun semua lini kehidupan manusia manapun (Sukadari, Suyata, dan Kuntoro, 2015).

Etnografi, yang muncul dari antropologi, dan diadopsi oleh para sosiolog, bersifat kualitatif metodologi yang cocok untuk studi tentang keyakinan, interaksi sosial, dan perilaku dari masyarakat kecil, yang melibatkan partisipasi dan 
observasi selama periode waktu tertentu, dan interpretasi data yang dikumpulkan. Pada tahap awal muncul keinginan peneliti untuk membuat etnografi tampil ilmiah, dan dengan pemikiran ini sebuah manual dibuat untuk orang-orang di lapangan, dengan satu set instruksi tentang bagaimana etnografi harus dilakukan. Sebagai seperti itu terlihat lebih akurat daripada deskripsi para pelancong, meskipun tidak di merasakan bahwa eksperimen ilmiah atau pengukuran kuantitatif dianggap akurat. Sebuah fitur dari positivisme, pendekatan ilmiah, adalah bahwa hasil dapat diuji, dan peneliti terpisah dari penelitian. Hal ini dipandang oleh para ahli etnografi sebagai gagal untuk menangkap aspek dari cara manusia berperilaku, pengaturannya dibuat-buat (Eriksson and Kovalainen, 2010: 149-63).

Di sisi lain, pendekatan naturalis lebih interpretatif, tidak dapat diverifikasi dengan tes, dan interpretasi peneliti sendiri adalah bagian dari proses. Tujuan dari etnografi kemudian memberikan gambaran analitis tentang budaya lain. eksplorasi fenomena tertentu, daripada pengujian hipotesis. Data terdiri dari akun tidak terstruktur dan analisis, yang memberikan interpretasi makna, dilakukan oleh peneliti, menggunakan observasi, deskripsi dan penjelasan.

Penelitian etnografi menggunakan lensa budaya untuk mempelajari kehidupan orang-orang di dalam suatu komunitas. Akar etnografi terletak pada kajian antropologi yang berfokus pada kajian sosial dan budaya aspek komunitas kecil di luar negeri. Para peneliti tinggal di antara penduduk dengan tujuan memahami budaya yang dibagikan oleh orang-orang ini. Jadi, para antropolog klasik adalah orang asing di lokasi lapangan mereka. Ini sering memakan waktu bertahun-tahun bagi mereka untuk memasuki budaya komunitas yang mereka pelajari. Untuk melakukannya, mereka harus belajar bahasa yang diperlukan untuk bersosialisasi dengan penduduk dan memahami kebiasaan, ritual, norma dan tindakan sehari-hari mereka (Eriksson and Kovalainen, 2010: 149-63).

Michael Genzuk memberikan pengertian penelitian etnografi, menurutnya, penelitian etnografi ialah suatu metode penelitian ilmu sosial. Penelitian ini sangat bergantung pada pengalaman pribadi dan kemungkinan partisipasi, dan bukan hanya observasi, oleh para peneliti. Dalam penlitian para etnografer sering bekerja tim dan multidisiplin. Dan dalam penelitian etnografi ini, titik fokus etnografi bisa termasuk bahasa intensif dan pembelajaran budaya, studi intensif dari satu bidang atau domain, dan perpaduan dari metode sejarah, observasi, dan wawancara (Genzuk, 2003).

Michael Genzuk menambahkan, bahwa penelitian etnografi yang khas menggunakan tiga jenis pengumpulan data: wawancara, observasi, dan dokumen. Dan pada gilirannya menghasilkan tiga jenis data: kutipan, deskripsi, dan kutipan dokumen, menghasilkan satu produk: deskripsi naratif atau sebuah narasi. Narasi pada aspek ini sering termasuk bagan, diagram, dan artefak tambahan yang membantu menceritakan "cerita". Metode etnografi dapat memberikan bentuk pada konstruksi baru atau paradigma, dan variabel baru, untuk pengujian empiris lebih lanjut di lapangan atau melalui metode ilmu sosial kuantitatif tradisional.

Penelitian etnografi menurut Creswell, bahwa penelitian etnografi diistilahkan dengan strategi. Menurutnya, bahwa penelitian etnografi ialah salah satu strategi penelitian kualitatif yang di dalamnya peneliti menyelidiki suatu kelompok kebudayaan di lingkungan yang alamiah dalam periode waktu yang cukup lama dalam pengumpulan data utama, data observasi, dan data wawancara (Creswell, 2014: 84). 
Studi etnografi sebagaimana dikenal dalam antropologi dikenal juga dalam batas-batas tertentu sebagai studi kasus. Syarat utama dalam studi etnografi adalah peneliti itu sendiri harus hidup di antara objek dan subjek yang ditelitinya untuk waktu yang relatif cukup bagi si peneliti untuk dapat hidup terintegrasi dengan masyarakat yang ditelitinya. Keberadaan peneliti dibutuhkan agar dapat mengembangkan kepekaannya dalam berpikir, merasakan dan menginterpretasikan hasilhasil pengamatannya dengan menggunakan konsepkonsep yang ada dalam pemikiran, perasaan-perasaan, dan nilai-nilai dari yang diteliti (Siddiq dan Salama, 2016: 64-75).

Spradley menjelaskan bahwa dalam penelitian etnografi penelitian medeskripsikan atas suatu kebudayaan, untuk memahami suatu pandangan hidup dari sudut pandang penduduk asli. Lebih dari itu, menurut Spradley dalam penelitian etnografi terjadi sebuah proses, dimana suatu kebudayaan mempelajari kebudayaan lain, untuk membangun suatu pengertian yang sistematik mengenai kebudayaan dari perspektif orang yang telah mempelajari kebudayaan tersebut. Dalam hal ini, etnografi menekankan pentingnya peran sentral budaya dalam memahami cara hidup kelompok yang diteliti (Creswell, 2014: 85).

Penelitian Etnografi terdapat beberapa ciri yang diantaranya merupakan ciri-ciri penting dijelaskan di bawah Peneliti etnografi atau etnografer, pertama, umumnya menghabiskan waktu setahun atau lebih untuk mempelajari budaya aspek kelompok atau masyarakat. Kedua, penelitian etnografi dianggap populer karena merupakan "kehidupan dan pekerjaan yang sangat mendalam. Ketiga, kami sering berargumen bahwa jika "hidup dan bekerja yang imersif", penelitian etnografi diadakan sesuai kebutuhan di dalam bidang "User-Centered Design" (UCD) atau "User Driven Development" (UDD) di mana peneliti diberikan "perhatian intensif" pada setiap tahapan proses desain. Keempat, penelitian etnografi yang singkat mungkin berguna untuk 'proyek desain yang berpusat pada pengguna. Kelima, penelitian etnografi melibatkan metode individual yaitu survei deskriptif, wawancara, interaksi, observasi khususnya observasi partisipan (Sharma, Sarkar, dan Behavior, 2019: 0-5).

Selanjutnya yang keenam, ini menghubungkan teknik pengumpulan data yang intensif dan ekstensif pada banyak variabel yang dapat diamati dalam waktu lama periode waktu dalam situasi naturalistik. Variabel yang dapat diamati secara alami terjadi dan dipelajari di mana mereka terjadi secara alami dan karena terjadi tanpa kendali Peneliti pada lingkungan dan kondisi percobaan. Ketujuh, studi etnografi menggunakan observasi partisipan sebagai teknik pengumpulan data primer bersama dengan Wawancara dengan anggota Grup atau komunitas. Di sini pengamatan peserta dapat diperpanjang dari satu bulan ke tahun tergantung pada sifat masalah. Kedelapan, perspektif emic-perspektif emic berarti bahwa Peneliti Etnografi memfokuskan bagaimana anggota budaya yang diteliti mempersepsikan budaya mereka. Kesembilan, perspektif etic- perspektif etic berarti bahwa peneliti mendekati beberapa pihak luar sehingga mengetahui bagaimana mereka memandang, dan menganalisis berbagai perilaku atau fenomena yang berkaitan dengan budaya di bawah belajar (Sharma, Sarkar, dan Behavior, 2019: 0-5).

Dari beberapa penjelasan terkait pengertian penelitian etnografi, dapat diperjelas bahwa penelitian etnografi ialah suatu proses yang memiliki tahapan tertentu dan memiliki karakteristik khas seperti; medeskripsikan suatu kebudayaan dan fenomana sosial, untuk memahami suatu pandangan hidup dari banyak aspek. Selain itu, yang menjadi khas dalam etnografi seperti menggunakan tiga jenis 
pengumpulan data: wawancara, observasi yang menuntun partisipan aktif, dan dokumentasi. Dan pada akhir studi ini, akan menghasilkan tiga jenis data: kutipan, deskripsi, dan kutipan dokumen, dan menghasilkan satu produk: deskripsi naratif atau sebuah narasi.

\section{Tahapan dan Teknik Analisis Data dalam Penelitian Etnografi}

Michael Genzuk menjelaskan bahwa, dalam penelitian etnografi terdapat tiga prinsip metodologi yang digunakan dalam penelitian etnografi, ketiga aspek ini juga sebagai ciri-ciri khusus dari penelitian etnografi. Selain itu, ketiga prinsip ini juga dasar bagi banyak kritik terhadap penelitian kuantitatif karena gagal menangkap kebenaran sifat perilaku sosial manusia; karena mengandalkan studi tentang pengaturan buatan atau tentang apa yang orang katakan daripada apa yang mereka lakukan; karena berusaha mereduksi dari arti dari apa yang bisa diamati; dan karena penelitian ini etnografi juga dapat mewujudkan fenomena sosial dengan memperlakukan fenomenal sosial yang didefinisikan lebih jelas dan statis daripada penelitain kuantitatif, dan sebagai produk mekanis dari faktor sosial dan psikologis (Genzuk, 2003).

Helen Sharp, Yvonne Dittrich and Cleidson de Souza mencoba merinci aspek dalam penelitian etnografi. Menurut keduanya ada empat aspek yang termauk ciri utama dalam penelitian etnografi yaitu; pada sudut pandang masyarakat, di mana letak fokus pada detail aspek kehidupan, sikap analitis, dan produksi untuk akuntabilitas akademik. Keempat aspek inilah yang menjadi dasar uatama sebagai pembeda studi etnografi dari penelitian observasi lainnya. Di subbagian berikutnya, masing-masing dijelaskan secara umum terlebih dahulu, dan kemudian diinterpretasikan di konteks penelitian rekayasa dengan menggunakan perangkat lunak secara empiris (Sharma, Sarkar, dan Behavior, 2019: 0-5).

Hemant Lata Sharma1 dan Chiranjit Sarkar, menjelaskan bahwa prosedur analisis data dalam penelitian etnografi, yaitu melibatkan aspek budaya, perilaku budaya dan makna aktifitas manusia. Penelitian ini terutama terbatas pada ekspresi verbal tetapi diperlukan kemudian uji statistik dan bakat numerik sebagai data sekunder. Pengumpulan data, analisis data, dan interpretasi data memainkan peran penting dalam studi penelitian etnografi. Penelitian etnografi ditujukan untuk mendeskripsikan budaya suatu kelompok atau sekelompok individu dengan sangat rinci dan kompleks secara intensif (Sharma, Sarkar, dan Behavior, 2019: 0$5)$.

Dalam etnografi, peneliti mengamati kegiatan mental, pengetahuan, membaca, adat istiadat, perkawinan, sandang, makan dan kegiatan budaya lainnya. Ini aspek budaya diungkapkan kepada peneliti dalam situasi kehidupan nyata. Dalam penelitian etnografi, peneliti ingin mengumpulkan informasi yang tersedia, informasi normal dan abnormal, apa yang mereka katakan dan bagaimana cara kerjanya. Bahkan, para peneliti budaya saat ini sangat menghargai dan banyak tertarik dan berpindah haluan untuk melakukan studi etnografi (Sharma, Sarkar, dan Behavior, 2019: 0-5).

Michael Genzuk, mendeskripsikan bahwa, dalam proses analisis dan interpretasi penelitian etnografi melibatkan pemeriksaan disiplin, wawasan yang kreatif, dan perhatian yang cermat terhadap tujuan studi penelitian. Kemudian, dalam analisis dan interpretasi data dalam penelitian etnografi ini yaitu proses yang terpisah secara konseptual. Proses analisis dimulai dengan mulai merakit bahan baku dari objek penelitian dan mendapatkan gambaran total dari 
keseluruhan proses. Peran peneliti dalam analisis mencakup kontinum dengan perakitan mentah data dari objek penelitian tentang satu komentar ekstrim dan interpretatif di sisi lain. Dan lebih lanjut, Genzuk menyatakan jika proses analisis dalam penelitian ini adalah proses menertibkan data, mengatur apa yang ada ke dalam pola, kategori, dan unit deskriptif dasar (Genzuk, 2003).

Selanjutnya, proses analisis data dalam penelitian etnografi melibatkan pertimbangan kata-kata, nada, konteks, non-verbal, konsistensi internal, frekuensi, keluasan, intensitas, kekhususan tanggapan dan gagasan besar. Sementara, bagian selanjutnya tentang strategi reduksi data yang Menginterpretasi, melibatkan dan melampirkan makna dan signifikansi pada analisis. Kemudian pada tahap ini peneliti juga menjelaskan dengan menggunakan pola deskriptif, dan mencari hubungan dan keterkaitan antar dimensi secara deskriptif. Setelah proses ini selesai, peneliti harus melaporkan interpretasi dan kesimpulannya (Genzuk, 2003).

Penelitian etnografi secara jelas pada dasarnya dilandasi oleh pemikiran fenomenologi. Dalam memahami suatu budaya aau situasi sosial lainnya, maka tahap-tahap yang harus dilalui, dimulai dari rincian (breakdown), resolusi (resolution), dan akhirnya pertalian (coherence). Hasil akhirnya adalah mencari pertalian dengan memperlihatkan: 1) mengapa suatu resolusi lebih baik dari yang lainnya; 2) menghubungkan suatu resolusi dengan pengetahuan yang lebih yang menyusun suatu tradisi; dan menjelaskan dan menerangkan, serta menampilkan reaksi dari anggota masyarakat yang diteliti (Wijaya, 2018: 1-9).

Pada riset etnografi, langkah pertama adalah melakukan seleksi proyekproyek etnografi, di mana peneliti harus mempertimbangkan berbagai investigasi yang akan dilakukan. Fieldwork etnografi dimulai ketika seorang etnografer menjawab atas pertanyaan etnografi yang disusun setelah seleksi berbagai persoalan etnografi. Pertanyaan etnografi disusun sedemikian rupa, sebagai bahan melakukan pengumpulan data etnografi. Pengumpulan data etnografi harus mempertimbangkan teknik-teknik yang akan diambil melalui pengamatan terlibat. Selama pengumpulan data berlangsung, peneliti harus merekam seluruh peristiwa, wawancara, dan semua hal yang berkaitan dengan pertanyaan etnografi yang dibuat sebelumnya (Naidoo, 2012).

Selanjutnya, selain karakteristik dari penelitian etngrafi, maka perlu juga diketahui tentang bagaimana perkembangan penelitian etnografi ini dari beberapa lintas sejarah. Menurut Kamarusdiana, terdapat beberapa fase perkembangan penelitian etnografi yang dapat kita ketahui dalam tiga fase yaitu, pertama, fase kemuculan penelitian etnografi yang dapat diketahui pada akhir abad ke-19. Fokus etnografi pada fase ini menitikberatkan pada perkembangan evolusi manusia. Hal ini dilihat dari bagaimana proses kelahiran manusia dan perkembangannya. Menurut Kamarusdiana, pada fase ini penelitian etnografis baru sebatas wacana saja. Dengan alasan bahwa peneliti pada fase ini sekadar melakukan studi kepustakaan, belum adanya praktik dan tinjauan di lapangan (Kamarusdiana, 2019: 113-28).

Kedua, fase etnografi modern (1915-1925). Pada fase ini tokoh sentralnya ialah Racliffe Brown dan Malinowski. Perbedaan dari etnografi pada masa awal, mereka tidak memandang suatu hal yang berhubungan dengan sejarah kebudayaan kelompok masyarakat. Mereka lebih menekankan kehidupan masa kini oleh anggota masyarakat sebagai way of life suatu masyarakat. Pada masa ini, etnografi mencoba mendiskripsikan dan membangun struktur sosial budaya 
masyarakat melalui interpretasi seorang peneliti. Tidak hanya itu, kemudian dilakukan perbandingan dengan sistem sosial untuk dapat ditarik kesimpulan tentang kaidah-kaidah umum yang ada di dalam masyarakat (Kamarusdiana, 2019: 113-28).

Ketiga, masa baru generasi pertama (etnografi baru generasi pertama/ 1960-an). Etnografi pada masa ini dikembangkan oleh Spradley yang menitikberatkan pada masyarakat mengorganisasikan budaya mereka dalam pikiran (mind), di mana kemudian diimplementasikan dalam kehidupan sosialnya. Bentuk sosial dan budaya disini menurut aliran ini adalah susunan yang ada didalam pikiran anggota masyarakat dan tugas peneliti untuk menguaknya keluar (Gibbons, Hammersley, dan Atkinson, 1986).

Oleh sebab itu, analisis dalam etnografi ini tidak hanya disandarkan pada asumsi dan interpretasi peneliti saja. Melainkan, dapat muncul dari pemahaman atas susunan pikiran anggota masyarakat. Karena pada dasarnya etnografi bertujuan untuk menemukan dan menggambarkan pola organisasi pikiran dari suatu masyarakat yang dikaji. Keempat, masa etnografi baru generasi kedua. Etnografi pada masa ini merupakan hasil sintesis dari pemikiran Spradley pada masa sebelumnya. Dalam pandangan Spradley etnografi tidak lagi dianggap sebagai metode untuk meneliti budaya luar (masyarakat kecil) yang terisolasi, tetapi masyarakat sendiri pula yang cukup multikultural. Pada intinya dari sintesis pemikiran Spradley ini berupaya untuk memperhatikan makna dari segala tindakan yang terjadi pada orang lain, dan ingin memahaminya melalui analisa kebudayaan (Gibbons, Hammersley, dan Atkinson, 1986).

Bertitik dari padangan tersebut, dalam penelitian etnogafi model Spraley terdapat tahapan yang harus dilaksanakan oleh peneliti. Tahapan ini terdiri atas dua belas tahapan, dimulai dengan menetapkan seorang informan kunci (key informant) yang merupakan informan yang handal atau akurat. Setelah itu peneliti melakukan wawancara. Selanjutnya, perhatian peneliti pada objek penelitian, dan memulai mengajukan pertanyaan deskriptif, dilanjutkan dengan analisis terhadap wawancara Berdasarkan hasil dari analisis wawancara selanjutnya peneliti melakukan analisis domain. Pada langkah berikutnya, peneliti sudah menentukan fokus, dan melakukan analisis taksonomi, selanjutnya peneliti mengajukan pertanyaan kontras, yang dilanjutkan dengan analisis komponensial. Hasil dari analisis komponensial, selanjutnya peneliti menemukan tema-tema budaya. Selanjutnya peneliti menuliskan laporan penelitian etnografi. Proses penelitian dimulai dari pemikiran yang luas, kemudian memfokus, dan meluas lagi (Genzuk, 2003). Untuk memperjelas bagaimana tahapan penelitian etnografi model analisis data Spradley, makan akan dijelaskan secara rinci dengan penjabaran sebagai berikut.

\section{Analisis Data Model Spradley}

Tahapan penelitian kualitatif model Spradley terdiri atas 12 tahapan dimulai dengan menetapkan seorang informan kunci (key informant) yang merupakan informan yang kredibel akan mampu membawa penelitia menuju objek penelitian yang tapat. Setelah itu peneliti melakukan wawancara. Selanjutnya, perhatian peneliti pada objek penelitian, dan memulai mengajukan pertanyaan deskriptif, dilanjutkan dengan analisis terhadap wawancara. Berdasarkan hasil dari analisis wawancara selanjutnya peneliti melakukan analisis domain. Pada langkah berikutnya, peneliti sudah menentukan fokus, dan 
melakukan analisis taksonomi, selanjutnya peneliti mengajukan pertanyaan kontras, yang dilanjutkan dengan analisis komponensial. Hasil dari analisis komponensial, selanjutnya peneliti menemukan tema-tema budaya. Kemudian, peneliti menuliskan laporan penelitian etnografi. Proses penelitian dimulai dari pemikiran yang luas, kemudian memfokus, dan meluas lagi (Wijaya, 2018: 1-9).

Bahkan, lain halnya seperti, dalam beberapa hal, Spradley tampaknya lebih menekankan pada penelitiannya yang lebih moderat dibanding antropolog lainnya. Hal ini dapat dilihat dari beberapa kasus dan contoh-contoh yang dikemukakan, ia telah mengambil bagian penting di dalam merubah citra antropologi sebagai ilmu yang hanya berbicara pada masyarakat-masyarakat primitif. Argumen yang dijadikan pijakan dasa dari hal ini bahwa menurut Spradley dalam Koes Winarno, antropologi harus dapat menjadi alat penting untuk memahami masyarakat yang saat ini sedang berkembang dan masyarakat yang multikultural di seluruh dunia. Dari sinilah etnografi ala Spradley relatif lebih seimbang atau berimbang. Selain itu, bahwa mayoritas antropolog setuju bahwa etnografi menjadi dasar antropologi yang kultural (Winarno, 2015: 257$65)$.

Pada riset etnografi, langkah pertama adalah melakukan seleksi proyekproyek etnografi, di mana peneliti harus mempertimbangkan berbagai investigasi yang akan dilakukan. Fieldwork etnografi dimulai ketika seorang etnografer menjawab atas pertanyaan etnografi yang disusun setelah seleksi berbagai persoalan etnografi. Pertanyaan etnografi disusun sedemikian rupa, sebagai bahan melakukan pengumpulan data etnografi. Pengumpulan data etnografi harus mempertimbangkan teknik-teknik yang akan diambil melalui pengamatan terlibat. Selama pengumpulan data berlangsung, peneliti harus merekam seluruh peristiwa, wawancara, dan semua hal yang berkaitan dengan pertanyaan etnografi yang dibuat sebelumnya (Winarno, 2015: 257-65).

Spradley membagi analisis data dalam penelitian kualitatif berdasarkan tahapan dalam penelitian kualitatif sebagai berikut:

\section{Gambar 1. (Tahapan analisis model Spradley)}

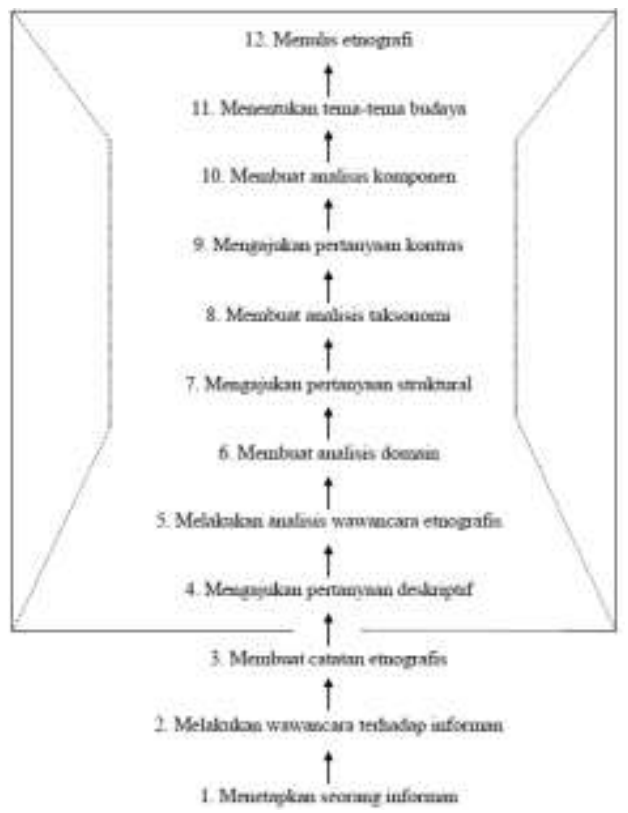

(Sumber: Sugiyono, Metode Penelitian Kombinasi, 2014, 335) 
1) Analisis Domain

a. Analisis Domain (Domain analysis)

Memperoleh gambaran yang umum dan menyeluruh dari obyek/ penelitian atau situasi sosial. ditentukan berbagai domain atau kategori. Diperoleh dengan pertanyaan grand dan minitour. Peneliti menetapkan domain tertentu sebagai pijakan penelitian selanjutnya. Makin banyak domain yang dipilih, maka akan semakin banyak waktu yang diperlukan untuk penelitian

b. Analisis Taksonomi (Taxonomic Analysis)

Domain yang dipilih tersebut selanjutnya dijabarkan lebih rinci, untuk mengetahui struktur internalnya. Dilakukan dengan observasi terfokus.

c. Analisis Komponensial (Componential analysis)

Mencari ciri spesifik pada setiap struktur internal dengan cara mengontraskan antar elemen. Dilakukan melalui observasi dan wawancara seleksi dengan pertanyaan yang mengontraskan (contras question)

d. Analisis Tema Kultural (Disorvering cultural theme)

Mencari hubungam diantara domain, dan bagaiman hubungan dengan keseluruhan, dan selanjutnya dinyatakan ke dalam tema/judul penelitian (Spradley, 1997: 148).

Analisis domain merupakan langkah pertama dalam penelitian kualitatif. Langkah selanjutnya adalah analisis taksonomi yang aktivitasnya yaitu mencari bagaimana domain yang dipilih itu dijabarkan menjadi lebih rinci. Selanjutnya, analisis komponensial aktivitasnya adalah mencari perbedaan yang spesifik setai rincian yang dihasilkan dari analisis taksonomi. Yang terakhir adalah analisis tema, yang aktivitasnya adalah mencari hubungan diantara domain, dan bagaimana hubungannya dengan keseluruhan, selanjutnya dirumuskan dalam suatu tema atau judul penelitian. Dalam hal tema Spradley (1980) menyatakan: "Theme as: a postulate or position, declare or implied, and usually controlling behavior or stimulating activity, which tacitly approved or openly promoted in society (Sugiyono, 2014: 334-335)

Analisis domain pada umumnya dilakukan untuk memperoleh gambaran yang umum dan menyeluruh tentang situasi sosial yang diteliti atau obyek penelitian. Data diperoleh dari grand tour dan minitour question. Hasilnya berupa gambaran umum tentang obyek yang diteliti, yang sebelumnya belum pernah diketahui. Dalam analisis ini informasi yang diperoleh belum mendalam, masih dipermukaan, namun sudah menemukan domain-domain atau kategori dari situasi sosial yang diteliti (Muhadjir, 2002: 120).

Dalam situasi sosial terdapat ratusan atau ribuan kategori. A category is an array of different objects that are treated as if they were equivalent (Spradley 1984). Suatu domain adalah merupakan kategori budaya (culture category) terdiri atas tiga elemen yaitu: cover, term, included term, dan semantic relationship. Cover term adalah nama suatu domain budaya, included term nama-nama yang lebih rinci yang ada dalam suatu kategori. Elemen ketiga dari seluruh domain budaya adalah hubungan semantic antar kategori. Mencari hubungan semantic ini merupakan hal yang penting untuk menemukan berbagai domain budaya (Sugiyono, 2014: 336). 


\section{2) Analisis Taksonomi}

Jadi analisis taksonomi adalah analisis terhadap keseluruhan data yang trekumpula berdasarkan domain yang telah ditetapkan. Dengan demian domain yang telah ditetapkan menjadi cover term oleh peneliti dapat diurai secara lebih rinci dan mendalam melalui anslisis taksonomi ini. Hasil analisis taksonomi dapat disajikan dalam bentuk diagram kotak (box diagram), diagram garis dan simpul (lines and node diagram) dan out line (Emzir, 2012: 133).

\section{3) Analisisi Komponensial}

Dalam analisis taksonomi, yang diuraikan adalah domain yang telah ditetapkan menjadi fokus. Melalui analisis taksonomi, setiap domain dicari elemen yang serupa dan serumpun. Ini diperoleh melalui obeservasi dan wawancara serta dokumentasi yang terfokus.

Pada analisis komponensial, yang dicari untuk diorganisasikan dalam bdomain bukanlah keserupaan dalam domain, tetapi justru yang memeiliki perbedaan atau yang kontras. Data ini dicari melalui observasi, wawancara dan dokumentasi yang terseleksi. Dengan teknik pengumpulan data yang bersifat triangulasi tersebut, jumlah dimensi yang spesifik dan berbeda pada setiap elemen akan dapat ditemukan (Muhadjir, 2002: 122).

\section{4) Analisis Tema Budaya}

Analisis tema atau discovering cultural themes, sesungguhnya merupakan upaya mencari "benang merah" yang mengintegrasikan lintasan domain yang ada. Dengan ditemukan benang merah dari hasil analisis domain, taksonomi, dan komponensial tersebut, maka selanjutnya akan dapat tersusun suatu "konstruksi bangunan" situasi sosial/obyek penelitian yang sebelumnya masih gelap atau remang-remang, dan setelah dilakukan penelitian, maka menjadi lebih terang dan jelas (Spradley, 1997: 178).

Intinya analisis tema kultural dapat dikatakan seorang peneliti menelususi atau mencari hubungan di antara beberapa tahapan tersebut, seperti domain, dan bagaimana hubungan dengan keseluruhan, dan selanjtnya dinyatakan ke dalam tema atau judul penelitian. Berdasarkan analisis budaya tersebut selanjutnya dapat disusun judul penelitian baru, apabila dalam judul dalam proposal berubah setelah peneliti memasuki lapangan (Spradley, 1997: 189).

Jelasnya dapat dikatakan bahwa model penelitian kualitatif Spradley atau juga sering disebut sebagai penelitian kualitatif etnografi ialah studi kualitatif terhadap diri individu atau sekelompok dengan tujuan mendeskripsikan setting sosial seperti karakteristik kultural. Kajiannya bersifat lebih mendalam secara sistematis dalam ruang dan waktu mereka sendiri. Penelitian etnografi pada mulanya banyak digunakan dalam penelitian antropologi, dan kini telah mengalami dinamika perkembangan masuk ke dalam berbagai bidang ilmu seperti kedokteran, kesehatan,bpsikologi,bdanbpendidikan serta ilmu sosial lainnya. Empat jenis analisis penelitian etnografi yaitu analisis domain, analisis taksonomi, analisis komponensial, dan analisis model. 


\section{Implementasi Penelitian Etnografi Model Spradley dalam Bidang Pendidikan}

Dalam beberapa dekade, bahwa fakta menunjukkan jika karya etnografi klasik semakin meningkat diambil dalam berbagai cara dalam penelitian kesehatan dan etnografi sebagai metodologi telah berubah dari waktu ke waktu. Kemudian, bentuk baru Etnografi telah berkembang sebagai respons terhadap pergeseran pemahaman dan untuk mendefinisikan kembali budaya, beberapa elemen kunci dari penelitian etnografi telah hilang. Pemeriksaan yang teliti terhadap beberapa studi etnografi menunjukkan bahwa etnografi berlanjut menjadi penting di bidang penelitian kesehatan. Dan lebih berkembang lagi etnogafi merabah ke dalam berbagai bidang seperti nutrisi, dalam bidang psikologi dan bahkan dalam bidang pendidikan.

Dalam perkembangannya, teknik analisis data model Spradley memberikan satu dari sekian tentang strategi yang komprehensif dalam metodologi penelitian kualitatif, untuk memahami atribut linguistik/bahasa dari budaya dan pengalaman suatu kelompok. Dalam model Spradley terdapat inovasi spesifik yang melibatkan dua pergeseran utama; yaitu, pertama, pergeseran fokus analisis dari budaya ke individu. Kedua, adanya fokus pada aspek semantik untuk dimasukkan pada teori pragmatis. Inovasi ini dipadang dalam dunia akademis memiliki komplikasi teoritis dan praktis. Selain itu, inovasi ini dilakukan melalui pelaksanaan dua studi kasus sebagai contoh dari pergesreran model analisis Spradley dalam dunia pendidikan. Jadi, di bagian metode studi kasus dijelaskan secara terpisah dengan perangkat-perangkat atau instrumen penelitian, kecuali sehubungan dengan penggunaan model Spradley secara paralel (Lee, NargundJoshi, dan Dennis, 2011: 42-57).

Dalam penelitian kualitatif analisis data dilakukan bersamaan dengan proses pengumpulan data di lapangan. Teknik analisis data semacam itu sudah lama dipakai dalam penelitian kualitatif tradisional yang berbentuk etnografi. Karena penelitian antropologi budaya sering dilakukan dalam jangka waktu yang lama, penundaan kegiatan menulis sampai proses pengumpulan data selesai, dipandang sebagai kesalahan serius dalam langkah analisis data penelitian (Nugrahani, 2014).

Kemudian, untuk memperjelas model analisis Spradley ini, maka, Jean S. Lee dkk. menggambarkan contoh secara kongkret tantang penggunaaan atau implemntasi dari model Spradley ini. Mereka mengambil dua studi kasus kualitatif yang disajikan dengan mengkaji manfaat metodologis, keterbatasan, dan kemungkinan mengadaptasi analisis wawancara etnografi secara rinci model Spradley. Adapun tujuannya mengartikulasikan dan memahami konseptualisasi subjek khusus pada objek yang diteliti. Studi kasus pertama yakni deskriptif, dan peneliti melihat bagaimana mata pelajaran fisika India dengan konseptualisasi guru tentang pengajaran dan pembelajaran sains (Lee, Nargund-Joshi, dan Dennis, 2011: 42-57).

Menurut Spradley, analisis etnografi dengan menggunakan berbagai tipe pertanyaan yang telah dibuat oleh peneliti, di mana pertanyaan-pertanyaan tersebut memiliki orientasi untuk mengungkapkan sistem dan makna budaya yang digunakan oleh masyarakat. Berbagai tahapan dalam analisis etnografis dijelaskan dalam pada gambar berikut ini: 
Gambar 2: ( Struktur penelitian model Spradley)

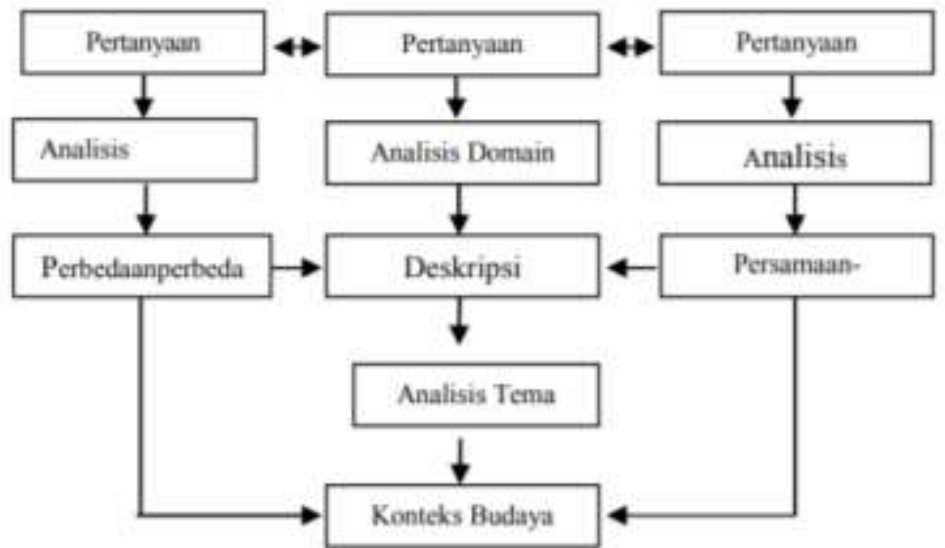

(Sumber: Jean S. Lee, Vanashri Nargund-Joshi, dan Barbara Dennis, 2011)

Melihat dari gambar tersebut di atas, maka dapat dijelakan bahwa dalam penelitian etnografi dengan langkah-langkahnya sebagai berikut. (1) Memilih masalah. Semua penelitian etnografi dimulai dengan permasalahan umum yang sama, yaitu apa makna budaya yang digunakan oleh masyarakat untuk mengatur tingkah laku dan menginterprestasikan pengalaman mereka. (2) Mengumpulkan data kebudayaan. Peneliti etnografi (etnografer) mulai mengajukan pernyataan deskriptif dengan melakukan observasi umum, dan mencatat data dalam catatan lapangan. (3) Menganalisis data kebudayaan. Analisis ini meliputi pemeriksaan ulang catatan lapangan untuk mencari simbol-simbol budaya serta mencari hubungan antara simbol-simbol tersebut. (4) Memformulasikan hipotesis etnografi. Hipotesis etnografis yang harus diformulasikan setelah mengumpulkan data awal, merupakan hipotesis hubungan yang harus diuji dengan cara mengecek hal-hal yang diketahui oleh informan. (5) Menulis etnografi. Penulis etnografi akan menstimulasi hipotesis dan kembali melakukan penelitian lapangan. Menurut Spradley, analisis etnografis dengan berbagai tipe pertanyaannya sesungguhnya mempunyai satu tujuan yang sama, yaitu mengungkapkan sistem makna budaya yang digunakan oleh masyarakat. Berbagai tahapan dalam analisis etnografis dijelaskan dalam uraian berikut ini (Lee, Nargund-Joshi, dan Dennis, 2011: 42-57).

Tahap pertama dalam model analisis Spradley ialah analisis domain. Pada tahap awal ii peneliti memperoleh gambaran umum dan menyeluruh dari objek penelitian atau situasi sosial yang diteliti. Melalui pertanyaan umum dan pertanyaan rinci peneliti menemukan berbagai kategori atau domain tertentu sebagai pijakan penelitan selanjutnya. Semakin banyak domain yang dipilih semakin banyak waktu yang diperlukan untuk penelitian. Data diperoleh dari grand tour dan monitour question. Hasilnya berupa gambaran umum tentang objek yang diteliti, yang sebelumnya belum pernah diketahui. Dalam analisis ini informasi yang diperoleh belum mendalam, masih dipermukaan, namun sudah menemukan domain-domain atau kategori dari situasi sosial yang diteliti (Wijaya, 2018: 1-9). Berikut contoh gambaran tentang tahap analisis domain:

Gambar 3: 
Kertas Kerja Analisis Domain

\begin{tabular}{ll}
\hline Hubungan Semantik & Salah satu jenis \\
\hline Bentuk & X adalah salah satu jenis dari Y \\
Hubungan Semantik & Salah satu kondisi \\
Bentuk & X adalah salah satu kondisi Y \\
Hubungan Semantik & Salah satu tempat dari \\
Bentuk & X adalah salah satu tempat dari Y \\
Hubungan Semantik & Salah satu karakteristik dari \\
Bentuk & X adalah salah satu karakteristik dari Y \\
Hubungan Semantik & Bagian dari \\
Bentuk & X adalah salah satu bagian dari Y \\
Hubungan Semantik & Salah satu cara \\
Bentuk & X adalah salah satu cara dari Y \\
Hubungan Semantik & Salah satu syarat \\
Bentuk & X adalah salah satu syarat dari Y \\
Hubungan Semantik & Salah satu tahapan \\
Bentuk & X adalah salah satu tahapan dari Y \\
Hubungan Semantik & Salah satu dari \\
Bentuk & Salah satu akibat dari \\
Hubungan Semantik & X adalah salah satu akibat dari Y \\
\hline
\end{tabular}

(Sumber: Jean S. Lee, Vanashri Nargund-Joshi, dan Barbara Dennis, 2011)

Jika melihat dari gambar tersebut di atas, dapat dikatakan bahwa pada tahap ini analisis taksonomi yang penah dilakukan oleh Jean S. Lee dkk untuk menyelidiki pemahaman koneksi dan hubungan antara domain yang berbeda dan membantu menemukan hubungan antara keyakinan dan tindakan guru dalam pembelajaran. Menurut keduanya, dalam penyelidikan guru menyebutkan teknik dan pra-syarat yang berbeda pembelajaran sains yang efektif. Selama observasi kelas dan lab serta wawancara, para guru menyebutkan pentingnya lingkungan interaktif untuk pengembangan konseptual siswa. Para guru mendeskripsikan karakteristik siswa kelas sains sebagai "pemikir kritis, penuh perhatian, dan bertanya tentang materi yang diajarkan. " Guru juga menyebutkan pengajaran harus langsung, lebih banyak kegiatan, sesuatu untuk menunjukkannya, dan belajar dengan praktik. Atribut ini terkait dengan pembelajaran sains dan pengajaran dapat tempatkan di bawah taksonomi "pembelajaran sains yang efektif". Analisis taksonomi membantu Nargund-Joshi melihat bagaimana guru menyatukan berbagai komponen untuk membangun secara efektif pengalaman belajar sains bagi siswanya.

Sebagai contoh praktis, dalam menerapkan analisis domain yaitu dalam penelitian pendidikan dengan menekankan pada aspek pemahaman individu secara konseptual yang memungkinkan untuk penyelidikan tetang kontradiksi intra-individu. Dalam tahapan ini bahwa Spradley memetakan secara rinci konseptualisasi individu yang disimpulkan dari pengamatan yang cermat terhadap formulasi semantik objek yang diteliti. Seperti yang dapat dilihat dari studi Jean S. Lee dkk, yang mendeksripsikan tentang kerumitan dan kehalusan dari konseptualisasi individual guru dapat diartikulasikan menggunakan versi Spradley yang disesuaikan dengan aspek pembelajaran guru dan siswa. Analisis komponensial terbukti paling berguna untuk pertanyaan substantif studi karena memungkinkan Nargund-Joshi menemukan perbedaan dalam cara guru mengekspresikan keyakinan mereka tentang proses belajar-mengajar dan cara 
mereka menjalankan proses itu sebagaimana dibuktikan oleh wawancara dan observasi masing-masing.

Tahap selanjutnya dalam model analisis Spradley yaitu analisis taksonomi. Analisis taksonomi yaitu: menjabarkan domain-domain yang dipilih menjadi lebih rinci, untuk mengetahui struktur internalnya. Dilakukan dengan observasi terfokus. Analisis terhadap keseluruhan data yang terkumpul berdasarkan domain yang telah ditetapkan. Dengan semikian domain yang telah ditetapkan menjadi cover term oleh peneliti dapat diurai secara lebih rinci dan mendalam melalui analisis taksonomi ini. Hasil analisis taksonomi dapat disajikan dalam bentuk diagram kotak (box diagram), diagram garis dan simpul (lines and node diagram) dan outline (Wijaya, 2018: 1-9). Contoh gambaran dari analisis ini sebagai berikut:

Gambar 4 (Bagan tahapan analisis Model Spradley)

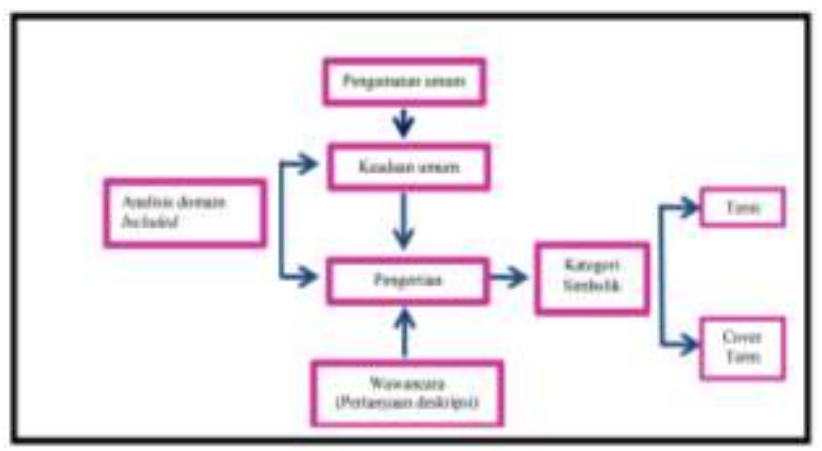

(Sumber: James P. Spradley, Metode Etnografi, 1997

Selanjutnya, tahap ketiga yaitu analisis komponensial, yang dapat dilihat pada gambar di bawah ini:

Gambar 5:

Klasifikasi Analisis Etnografi

\begin{tabular}{lll}
\hline Wawancara & Analisis & Pengamatan \\
\hline Pertanyaan deskriptif & Domain & Pertanyaan deskriptif \\
Pertanyaan struktur & Taksonomi & Pertanyaan terfokus \\
Pertanyaan kontras & Komponensial & Pertanyaan terseleksi \\
\hline \multicolumn{2}{l}{ Sumber: dimodifikasi dari Basrowi \& Suwandi } & (2008:212)
\end{tabular}

Gambar tersebut di atas, sebagai contoh pada analisis komponensial dalam studi penelitian etnografi model Spradley, bahwa peneliti menemukan indikasi dari persepsi siswa misalnya, tentang bilangan genap yang membutuhkan paritas (kesamaan nilai). Jika dianalogikan, bahwa angka 6 adalah bilangan genap, karena memiliki dua pasang 3 ditambah 3. Pada kasusnya, dalam persepsi beberapa siswa menyebut nol memiliki pasangan, karena memiliki dua pasang angka nol. Padahal beberapa siswa yang lain tidak menganggap nol memiliki paritas (kesamaan), karena angka nol bukanlah angka. Klaim tentang angka nol adalah bilangan genap dibandingkan dengan argumen nol adalah bilangan ganjil. Dan inilah contoh dari tahap analisis komponensial. Analisis komponensial ini dianggal oleh Jean S. Lee dkk. menjadi media yang digunakan Lee dalam penelitiannya, untuk menggambarkan adanya mis-konsepsi siswa yang 
beranggapan bahwa nol menjadi genap atau ganjil (Lee, Nargund-Joshi, dan Dennis, 2011: 42-57).

Tahapan selanjutnya, dalam model analisis Spradley ini ialah analisis tema. Setelah ketiga tahap ini dilakukan maka, tahap akhit melakukan analisis tema. Analisis tema kultural yaitu mencari hubungan di antara domain, dan bagaimana hubungan dengan keseluruhan, dan selanjtnya dinyatakan ke dalam tema atau judul penelitian. Berdasarkan analisis budaya tersebut selanjutnya dapat disusun judul penelitian baru, apabila dalam judul dalam proposal berubah setelah peneliti memasuki lapangan. Pencarian untuk hubungan antar domain dan caranya mereka terkait dengan budaya secara keseluruhan (Lee, Nargund-Joshi, dan Dennis, 2011: 42-57). Berikut gambaran dari analisis tema:

Gambar 6:
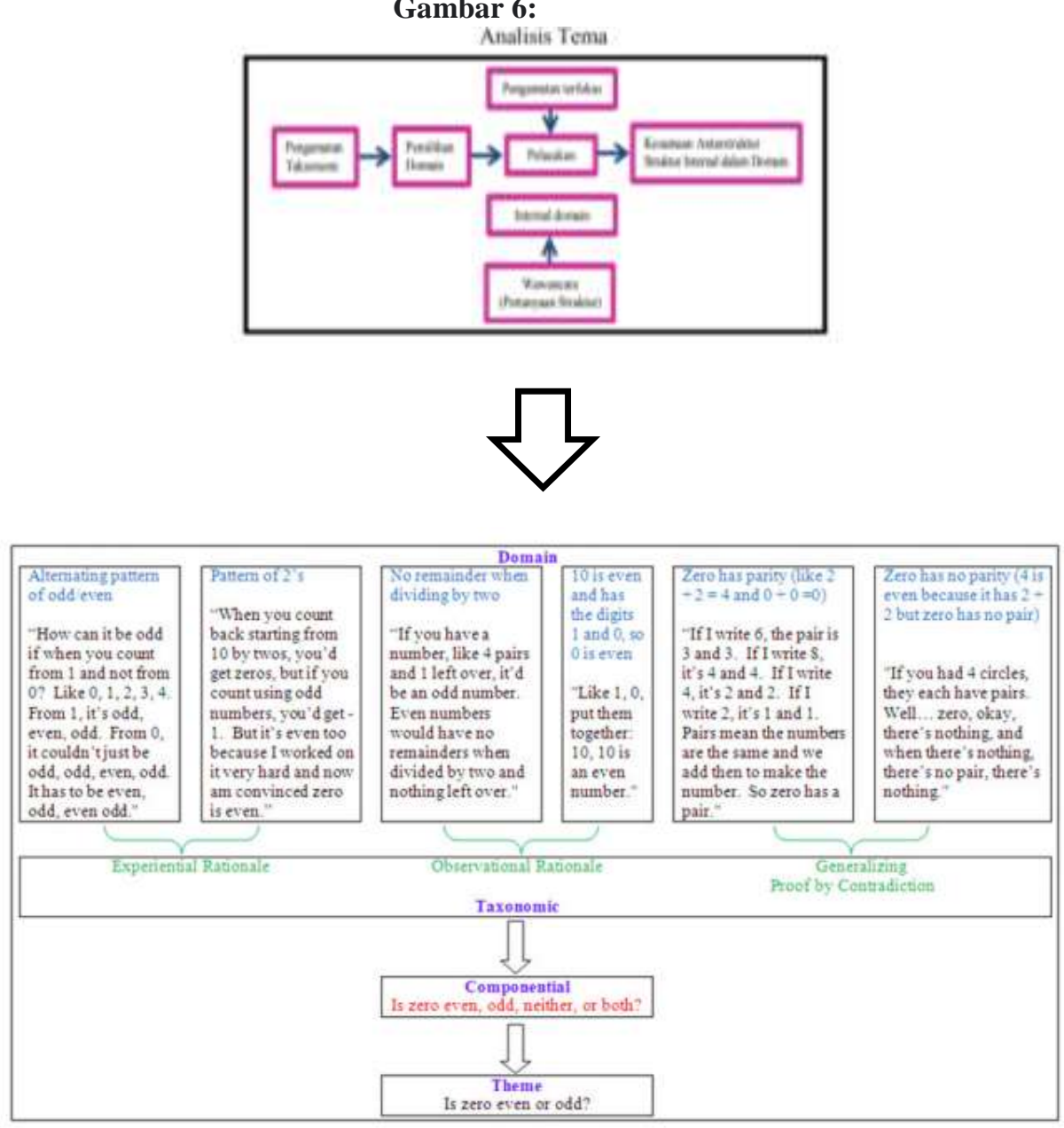

(Sumber: Jean S. Lee, Vanashri Nargund-Joshi, dan Barbara Dennis, 2011)

Pada bagian ini, Lee dkk. menunjukkan bahwa meskipun konsep matematika siswa bisa menjadi sangat istimewa dan sulit untuk diartikulasikan, prosedur analitis Spradley memungkinkan untuk menjelaskan konseptualisasi implisit dari "nol". proses pengembangan salah satunya tema (konseptualisasi nol sebagai bilangan genap atau ganjil yang diperdebatkan) untuk menampilkan cara terbaik diterapkan ke seluruh studi (Lee, Nargund-Joshi, dan Dennis, 2011: 42$57)$.

Tahap akhir dalam penelitian ini yaitu menulis etnografi. Pelaksanaan dalam tahap ini setelah semua tahap dilalui dan analisis, maka seorang peneliti 
harus melawati proses akhir yaitu membuat atau menulis etnografi sebagai hasil dari semua komonen yang telah dianalisis pada setiap tahap. Etnografi harus ditulis, sehingga budaya atau kelompok dapat dibawa ke kehidupan nyata, membuat pembaca merasa bahwa mereka memahami orang-orang dan cara hidup mereka atau situasi dan orang-orang di dalamnya. Laporan etnografis dapat berbentuk panjang dari beberapa halaman untuk satu atau dua volume. Penulisan harus rinci dan konkret, tidak umum atau samar (Wijaya, 2018: 1-9).

Menggunakan langkah-langkah analitis Spradley membantu mengungkap keyakinan guru sains tentang mengajar dan pembelajaran dan konsepsi siswa tentang angka nol. Keempat langkah analisis dibantu mencapai tema, tetapi analisis taksonomi dan komponensial merupakan alat yang ampuh dua studi kasus ini. Kedua analisis ini membantu peneliti melihat koneksi internal di dalamnya domain dan akhirnya memahami keyakinan diam-diam guru dan keterlibatan siswa dalam matematika (Lee, Nargund-Joshi, dan Dennis, 2011: 42-57).

Model analisis Spredley yang digunakan oleh Lee dkk. dalam dunia pendidikan dan pembelajaran bertujuan untuk membandingkan keyakinan yang diungkapkan guru dan keyakinan yang mana benar-benar diekspresikan dalam pengajaran para guru. Untuk memahami titik kritis ini, di awal menggunakan analisis komponen. Selanjutnya yaitu mencari konseptualisasi siswa tentang angka nol dan bagaimana hal itu terjadi. Beranjak pada tahap analisis taksonomi yang membantu mengungkap cara siswa berada membenarkan mengapa angka nol bisa menajdi genap genap atau ganjil. Keyakinan dan konsep dapat disimpulkan melalui tindakan dan kata-kata (Lee, Nargund-Joshi, dan Dennis, 2011: 42-57).

Dengan demikan, dapat diperjelas dari contoh yang diberikan diatas mulai dari tahap awal sampai tahap akhir dalam model analisis Spradley ini yaitu bhawa alat analisis Spradley membantu mengembangkan pemahaman tentang keyakinan guru dan konsepsi siswa tentang nol.

Sebagai tambahan, menurut Spradley, bagian penting dari etnografi adalah bahwa teknik utama penelitian ini dengan mengggunakan pengamatan terlibat (participant observation). Artinya, pengamatan terlibat merupakan bagian yang tak terpisahkan dalam etnografi. Sedang di sisi lain etnografi menjadi bagian penting dari antropologi, sehingga dengan cara yang sama dapat dikatakan etnografi, pengamatan terlibat, dan antropologi merupakan bagian yang selalu menyatu. Bahkan Spradley menjelaskan bahwa "Ethnography is the work of describing a culture" (ethnografi merupakan pekerjaan untuk menjelaskan sebuah budaya) (Spradley, 1997: 189).

Menurut Spradley, setiap deskripsi etnografi merupakan suatu terjemahan yang di dalamnya terdapat penggunaan istilah-istilah dan makna-maknanya yang asli (native), di samping juga mengunakan istilah yang digunakan etnografer. Spradley mengidentifikasi bahwa terdapat enam tipe deskripsi yang menggambarkan perbedaan dalam hal sejauh mana suatu deskripsi merefleksikan sudut pandang penduduk asli (Siddiq dan Salama, 2016: 64-75).

Spradley mengilustrasikan bagaimana ia melakukan riset komunitas gelandangan. Entri utama dalam membuat catatan etnografi, bahasa harus dapat diatasi oleh peneliti. Prinsip identifikasi bahasa ditegaskan secara sederhana, mengidentifikasikan bahasa yang digunakan untuk masing-masing judul catatan lapangan. Metode yang digunakan adalah meliputi penulisan beberapa hal dalam kurung, tanda kutip, tanda kurung besar, yang harus meliputi identifikasi 
pembicara. Tujuannya adalah agar didapatkan catatan etnografis yang menggambarkan berbagai perbedaan yang sama dalam penggunaan bahasa sebagaimana situasi lapangan yang aktual (Winarno, 2015: 257-65).

Studi kedua adalah eksplorasi ujian konseptualisasi nol siswa kelas lima di kelas matematika dalam skala besar kota AS bagian selatan. Dalam kedua studi tersebut, para peneliti menggunakan elemen analisis dari Spradley (domain, taksonomi, komponensial, dan tematik) dengan inovasi teoritis yang dijelaskan atas. Mereka menggunakan prosedur analitik dari DRS Spradley untuk mengartikulasikan semantik yang dapat diamati struktur, merekonstruksi struktur pragmatis implisit, dan dari sana mengidentifikasi individu konseptualisasi. Dalam kasus kami, teknik analitik ini mengungkapkan kerumitan cara masuk yang (a) keyakinan dan pengesahan guru sains memengaruhi pengajaran dan pembelajaran sains mereka dan (b) siswa kelas lima menganggap angka nol (Lee, Nargund-Joshi, dan Dennis, 2011: 42-57).

Dengan demikian, dari pembahasan di atas, bahwa dapat dikatakan analisis Spradley dapat dilakukan pada berbagai bidang ilmu, termasuk dalam bidang pendidikan. Hal ini dapat dilihat dari contoh yang telah dinyatakan oleh Jean S. Lee dkk. bagaimana tahapan etnografi dalam bidang pendidikan meninjau dari dua studi kasus tentang murid dan guru dalam pembelajaran.

\section{Kesimpulan}

Setelah membahas, dan mengkaji tentang pendekatan etnografi dalam dan implementasinya dalam bidang pendidikan. Maka, dapat disimpulkan bahwa Empat jenis analisis penelitian etnografi dalam model Spredley yaitu analisis domain, analisis taksonomi, analisis komponensial, dan analisis model (hasil etnografi). Tahapan penelitian kualitatif model Spradley terdiri atas 12 tahapan dimulai dengan menetapkan seorang informan kunci (key informant) yang merupakan informan yang handal atau akurat. Setelah itu peneliti melakukan wawancara. Selanjutnya, perhatian peneliti pada objek penelitian, dan memulai mengajukan pertanyaan deskriptif, dilanjutkan dengan analisis terhadap wawancara Berdasarkan hasil dari analisis wawancara selanjutnya peneliti melakukan analisis domain. Pada langkah berikutnya, peneliti sudah menentukan fokus, dan melakukan analisis taksonomi, selanjutnya peneliti mengajukan pertanyaan kontras, yang dilanjutkan dengan analisis komponensial. Hasil dari analisis komponensial, selanjutnya peneliti menemukan tema-tema budaya. Dan di akhir, peneliti menuliskan laporan penelitian etnografi. Penelitian etnografi pada saat ini tidak tidak dibatasi dalam bidang tertentu saja, namun dapat dilakukan dalam semua bidang, termasuk dalam pendidikan. 


\section{Daftar Pustaka}

Creswell, John W. Research Design: Qualitative, Quantitative and Mixed Methods Approaches. 4 ed. London: Sage Publication, Inc, n.d. http://fe.unj.ac.id/wp-content/uploads/2019/08/Research-Design_QualitativeQuantitative-and-Mixed-Methods-Approaches.pdf.

Eriksson and Kovalainen. "ETHNOGRAPHIC RESEARCH The emic and etic perspectives." Qualitative Methods in Business, 2010, 149-63. https://study.sagepub.com/sites/default/files/Eriksson and Kovalainen.pdf.

Farida Nugrahani. Metode Penelitian Kualitatif dalam Penelitian $\begin{array}{lllll}\text { Pendidikan Bahasa. } & \text { Buku. } & \end{array}$ http://lppm.univetbantara.ac.id/data/materi/Buku.pdf.

Gibbons, Jacqueline A., Martyn Hammersley, dan Paul Atkinson. Ethnography: Principles in Practice. Contemporary Sociology. Vol. 15, 1986. https://doi.org/10.2307/2070079.

Heinz Herman Kruger. "The Importance of Qualitative Methods in the German Educational Science Chapter Author," 52-74, 2010. https://www.jstor.org/stable/pdf/j.ctvbkjvmn.5.pdf?ab_segments=0\%2Fbasic_sear ch_SYC-5462\%2Fcontrol\&refreqid=fastlydefault\%3Ac6f9239fb83ff17ea31f667d8ac376f1.

Kamarusdiana, Kamarusdiana. "Studi Etnografi Dalam Kerangka Masyarakat Dan Budaya." SALAM: Jurnal Sosial dan Budaya Syar-i 6, no. 2 (2019): 113-28. https://doi.org/10.15408/sjsbs.v6i2.10975.

Lee, Jean S., Vanashri Nargund-Joshi, dan Barbara Dennis. "Progressing through the Haze in Science and Mathematics Education Research: Contemporary Use of Spradley's Qualitative Inquiry in Two Case Studies." International Journal of Qualitative Methods 10, no. 1 (2011): 42-57. https://doi.org/10.1177/160940691101000104.

Michael, Genzuk. "Genzuk: A Synthesis of Ethnographic Research," 2003. http://www-bcf.usc.edu/ genzuk/Ethnographic_Research.html.

Naidoo, Loshini. "Ethnography: An Introduction to Definition and Method." An Ethnography of Global Landscapes and Corridors, 2012. https://doi.org/10.5772/39248.

Salama, Muhamamd Siddiq dan Hartini. "Etnografi Sebabagi Teori dan Metode." Kordinat 4, no. 1 (2016): 64-75. http://journal.uinjkt.ac.id/index.php/kordinat/article/view/11471.

Sharma, Hemant Lata, Chiranjit Sarkar, dan Academic Help-seeking Behavior. "Ethnography research: an overview." International Journal of Advance and Innovative Research 6, no. 2 June (2019): 0-5. https://www.tandfonline.com/doi/abs/10.3109/10826089709035470?journalCode =isum 20 .

Sukadari, Suyata Suyata, dan Shodiq A. Kuntoro. "Penelitian Etnografi Tentang Budaya Sekolah dalam Pendidikan Karakter di Sekolah Dasar." Jurnal Pembangunan Pendidikan: Fondasi dan Aplikasi 3, no. 1 (2015): 58-68. https://doi.org/10.21831/jppfa.v3i1.7812.

Wijaya, Hengki. "Analisis Data Kualitatif Model Spradley." Research Gate, no. March (2018): 1-9. https://repository.sttjaffray.ac.id/media/269015analisis-data-kualitatif-model-spradley-aa4e183c.pdf.

Winarno, Koes. "Memahami Etnografi Ala Spradley." Smart 1, no. 2 (2015): 257-65. https://doi.org/10.18784/smart.v1i2.256. 
Windiani, dan Farida Nurul. "Menggunakan metode etnografi dalam penelitian sosial." Dimensi jurnal sosiologi 9, no. 2 (2016): 87-92. http://trilogi.ac.id/journal/ks/index.php/PAUD/article/download/181/151. 